\title{
Диагностика болезней моркови столовой с использованием лампы
} Вуда

\section{Л.М. Соколова, Е.А. Седов, С.А. Масловский, М.Е. Замятина, Н.А. Карпова}

Представлен способ модернизации метода ломтиков с использованием источника УФ-излучения (лампы Вуда) при оценке устойчивости селекционного материала моркови к грибным болезням из родов Alternaria и Fusarium. Установлено наличие флуоресценции пораженной ткани до наступления видимых признаков развития мицелия на ломтиках моркови. Возможна оценка устойчивости моркови на 1-3-сутки после заражения ломтиков, что позволяет ускорить селекционную работу, а также метод можно использовать для контроля фитосанитарного состояния и выявления скрытых болезней маточников моркови перед их высадкой.

Ключевые слова: морковь, Alternaria, Fusarium, устойчивость, лампа Вуда, УФ-излучение, флуоресценция.

Л ампа Вуда излучает исключительно в наиболее длинноволновой «мягкой» части ультрафиолетового диапазона и имеет сравнительно слабое видимое свечение. Ее широко применяют в криминалистике, медицине, ветеринарии. Данные по ее применению с целью оценки состояния плодоовощной продукции разрознены и носят единичный характер. В работе представлены результаты исследований по разработке метода ускоренной оценки моркови на устойчивость к грибным болезням из родов Alternaria и Fusarium с использованием лампы Вуда. Представленный метод является усовершенствованием традиционно применяемого метода заражения ломтиков и предусматривает их оценку визуальным методом в условиях УФ-излучения. Установлено наличие флуоресценции пораженной ткани до наступления видимых признаков развития мицелия на ломтиках моркови.

Проведенные исследования свидетельствуют о том, что лампу Вуда следует использовать для контроля фитосанитарного состояния и выявления скрытых болезней маточников моркови перед их высадкой.

Пригодность сортов и гибридов моркови столовой к длительному хранению является одним из основных хозяйственно-ценных признаков этой культуры. В значительной степени она определяется их устойчивостью к грибным и бактериальным болезням, проявляющимся при хранении.
По данным ряда авторов величина потерь, обусловленная, болезнями, может достигать 20-25\%, а в отдельных случаях - до 40-60\%. [1, 2].

Характер проявления болезней при хранении моркови зависит от многих абиотических и биотических факторов, таких как погодные условия вегетационного периода, уровень агротехники, физиологическое состояние продукции к моменту уборки, технологии уборки, послеуборочной товарной доработки, технологии и параметрах хранения. Но биологической основой лежкости моркови, как и других овощных культур, являются ее сортовые особенности.

Исследования в области повышения иммунитета столовой моркови к болезням, проявляющимся во время хранения являются одним из приоритетных направлений в селекционной работе с этой культурой. Лаборатория хранения и лаборатория селекции столовых корнеплодов и луков ВНИИО филиала ФГБНУ ФНЦО, начиная с 2000 года, ведет работу по оценке сортов и гибридов моркови по их сохраняемости [3], которая предусматривала фитопатологические анализы. Были выделены образцы, устойчивые к таким грибным болезням из родов Alternaria и Fusarium, так же серая гниль и белая гниль.

С целью совершенствования селекционной работы в данном направлении лабораторией селекции столовых корнеплодов и луков проводится фитопатологическая оценка не только сортов и гибридов, но и родительского материала, с целью выявления доноров комплексной устойчивости к болезням при хранении. Так, В.И. Леуновым и др. [4], Л.М. Соколовой и др. [5] разработана методика ускоренной селекции моркови на устойчивость к грибным болезням из родов Alternaria и Fusarium. Эта методика предусматривает испытание сортообразцов на двух искусственных инфекционных фонах и комплекс лабораторных методов, которые позволяют выделить материал, устойчивый к изучаемым болезням.

Необходимо отметить, что листовая диагностика болезней моркови не всегда объективно характеризует поражаемость корнеплодов при хранении [6].

На сегодняшний день существует потребность в разработке ускоренного метода диагностики устойчивости моркови к болезням на корнеплодах, не требующего сложной приборной базы и значительных затрат времени. В основу разработки нового метода оценки корнеплодов, может быть положен метод заражения ломтиков чистой культурой возбудителя, разработанный и успешно апробированный во ВНИИО.

Целью исследований, проводившихся в 2018-2019 годах на базе лаборатории селекции столовых корнеплодов и луков ВНИИО-филиала ФГБНУ ФНЦО и кафедре технологии хранения и переработки плодов и овощей ФГБОУ ВО РГАУ-МСХА имени К.А. Тимирязева, являлась модернизация метода «ломтиков» с использованием источника УФизлучения (лампы Вуда) при оценке внутренних скрытых проявлений болезней на корнеплодах моркови столовой.

Материал и метод проведения исследований. В качестве объекта был взят слабовосприимчивый сорт моркови НИИОХ 336.

Метод ломтиков: отобранные корнеплоды моркови тщательно от- 




Рис. 1 - Внешний вид ломтиков моркови при закладке опыта. При нормальном освещении (a - Alternaria, б - Fusarium) и при освещении лампой Вуда (в - Alternaria, г - Fusarium).
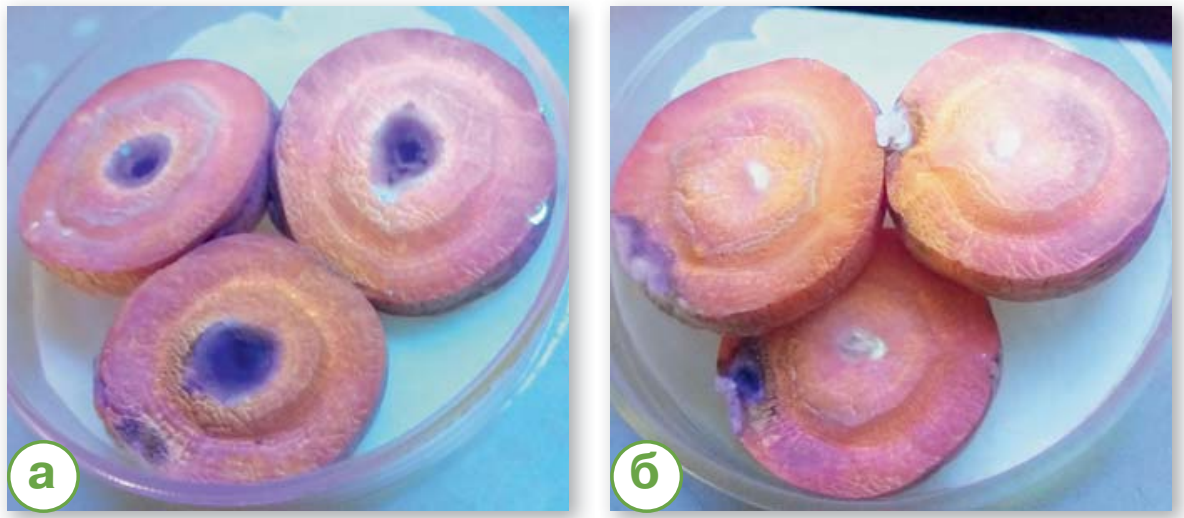

Рис. 2 Оценка ломтиков моркови столовой в условиях УФ излучения на седьмые сутки (a - Alternaria, б - Fusarium).

мываются в воде. Стерилизацию корнеплодов проводят в стеклянной посуде, с разведением в воде 0,1\% раствора $\mathrm{KMnO}_{4}$ в течение 10 мин., затем корнеплоды промывают дистиллированной водой. Корнеплоды режутся на диски толщиной 0,5 см, отступая от кончика корнеплода 2 см. Диски раскладываются в стерильные чашки Петри, выстланные стерильной фильтровальной бумагой с увлажненной дистиллированной водой

Затем в центр дисков помещают мицелий гриба (кусочек размером 2х2 мм) и оставляют чашки Петри при комнатной температуре или ставят в термостат с температурой 20-23 ${ }^{\circ} \mathrm{C}$.

Учеты по данному опыту проводят каждые сутки, длительность опыта 7 суток. Данный метод ломтиков уместно применять в после уборочный период для прогнозирования лежкости моркови столовой (в нашем случае маточников).

Обсуждение результатов. На рисунке 1 представлен внешний вид ломтиков моркови при нормальном освещении и при освещении лампой Вуда непосредственно после закладки опыта «ломтики». На рисунке $1(\mathbf{a}, \mathbf{6 )}$ при визуальном рассмотрении ломтиков моркови столовой видно, что признаков пораженной внутренней ткани отсутствует. Ярко видны мицелиальные блочки культур Alternaria (a) и Fusarium (б) на ломтика. Также на рисунке 1 (в, г) показаны те же самые чашки Петри но уже с просветкой УФ-излучения, и видно, что вследствие флуоресценции больная ткань моркови приобретает слабое фиолетовое свечение.

Учеты проводили каждые сутки на протяжении 7 суток с последующей фотофиксацией в затемненном помещении.

На седьмые сутки учета по Alternaria у слабовосприимчивого сорта НИИОХ 336 в условиях УФ излучения на срезах сильнее проявляются светлоокрашенные участки, четко отличающиеся по цвету от здоровой ткани. При этом развитие мицелий четко остается в пределах сердцевины (рис. 2 (а) Alternaria).

На седьмые сутки по Fusarium рост и развитие мицелиальных блочков не наблюдается, но при этом скрытая внутренняя инфекция при УФ - излучении проявляется очень четко (рис 2, Fusarium (б)).

В результате проведенных исследований можно сказать, что используя лампу Вуда можно проводить отбор корнеплодов моркови столовой, по признаку поражения внутренней скрытой инфекции после хранения перед высадкой маточного материала в грунт.

\section{Библиографический список}

1.Дьяченко В.С. Исследование и обоснование путей снижения потерь корнеплодов и лука при хранении: автореф. дисс... доктора с.- Х. наук. М., 1976. $36 \mathrm{c.}$

2.Мурашова Ю.В. Болезни моркови при хранении и методы борьбы с ними в условиях Курганской области: автореф. дисс... канд. с.- х. наук. Курган, 2006. 17 с. 3.Технология хранения и реализации сортов и гибридов корнеплодных культур [Электронный ресурс] URL: http://vniioh.ru/wp-content/uploads/2012/02 ruk_2010_Tehnologiya_hraneniya.pdf. Дата обращения: 11.04 .19

4.Методы ускоренной селекции моркови столовой на комплексную устойчивость к грибным заболеваниям (альтернариоз и фузариоз): методика / В.И. Леунов и др. М.: ГНУ ВНИИО, 2011. 56 с.

5.Соколова Л.М. Устойчивость сортообразцов моркови к болезням при хранении в зависимости от инфекционного фона и послеуборочного фитосанитарного состояния растений / Л.М. Соколова и др. // Аграрный научный журнал. 2019. № 1. С. 26-31. DOI: 10.28983/ asj.v0i1.687

6.Сравнительная оценка современных сортов и гибридов моркови на устойчивость к болезням при хранении / Л.М. Соколова, С.А. Масловский, М.Е. Замятина, Н.А. Карпова // Международный научно-исследовательский журнал. 2018. № 4. С. 73-76. DOI: 10.23670/ IRJ.2018.70.016 


\section{Об авторах}

Соколова Любовь Михайловна, канд. с. - х. наук, с.н.с. отдела селекции и семеноводства, ВНИИО-филиал ФГБНУ ФНЦО

E-mail: Isokolova74@mail.ru

Седов Егор Александрович, стуДеНТ, ФГБОУ ВО РГАУ-МСХА ИменИ К.А. Тимирязева.

E-mail: eg.sedov@yandex.ru

\section{Масловский Сергей}

Александрович, канд. С. - Х. наук, ДОценТ, ФГБОУ ВО РГАУ-МСХА ИМенИ К.А. Тимирязева.

E-mail: maslowskij@i.ua

Замятина Марина Евгеньевна, ассИстент, ФГБОУ ВО РГАУ-МСХА Имени К.А. Тимирязева.

E-mail: marina.zamyatina@list.ru

Карпова Наталья Александровна, маГИстрант, ФГБОУ ВО РГАУ-МСХА имени К.А. Тимирязева.

E-mail: natti94@mail.ru

Diagnosing of carrots diseases using lamp of Wood

L.M. Sokolova, $P h D$, senior research

fellow of department of breeding and seed production, ARRIVG-branch of FSBSI FSVC. E-mail: Isokolova74@mail.ru
E.A. Sedov, student, RGAU-MSA after K.A. Timiryazev. E-mail: eg.sedov@yandex.ru S.A. Maslovskii, PhD, associate professor, RGAU-MSA after K.A. Timiryazev.

E-mail: maslowskij@i.ua

M.E. Zamyatina, assistant, RGAU-MSA

after K.A. Timiryazev.

E-mail: marina.zamyatina@list.ru

N.A. Karpova, undergraduate, RGAU-MSA

after K.A. Timiryazev.

E-mail: natti94@mail.ru

Summary. The method of modernization of the method of slices using a source of UV radiation (lamp of Wood) in assessing the resistance of the breeding material of carrots to fungal diseases of the genera Alternaria and Fusarium is presented. The presence of fluorescence of the affected tissue before the onset of visible signs of mycelium development on carrot slices was established. It is possible to evaluate the sustainability of carrots on 1-3 days after infection, slices, allowing to accelerate the breeding work, and the method can be used to control the phytosanitary state and the detection of latent disease of carrots before their planting.

Keywords: carrots, Alternaria, Fusarium, stability, wood lamp, UV radiation, fluorescence.
Надежный партнер

«Роагролизинг» предлагает башкирскому селу сельхозтехнику на уникальных условиях.

В связи с острой необходимостью обеспечить каждого работника села качественной и современной техникой в феврале 2019 года Росагролизинг объявил о перезапуске самой востребованной среди аграриев программы «Обновление парка техники 2.0», отменив при этом существовавшие ранее региональные квоты.

В рамках обновленной программы ОПТ 2.0 Росагролизинга аграрии страны могут приобрести технику на уникальных условиях: полное отсутствие авансового платежа для самоходной техники, ставка вознаграждения - 3\%, отсрочка первого платежа - шесть месяцев, гарантийное обеспечение не требуется.

Источник: www.zerno.ru

\section{XVI специализированная выставка}



\section{Уважаемые коллеги!}

\section{Ассоциация «Теплицы России»}

приглашает Вас принять участие в XVI специализированной выставке «Защищенный грунт России» - уникальной деловой среде для налаживания контактов и получения информации о ключевых тенденциях развития тепличного овощеводства в Российской Федерации.

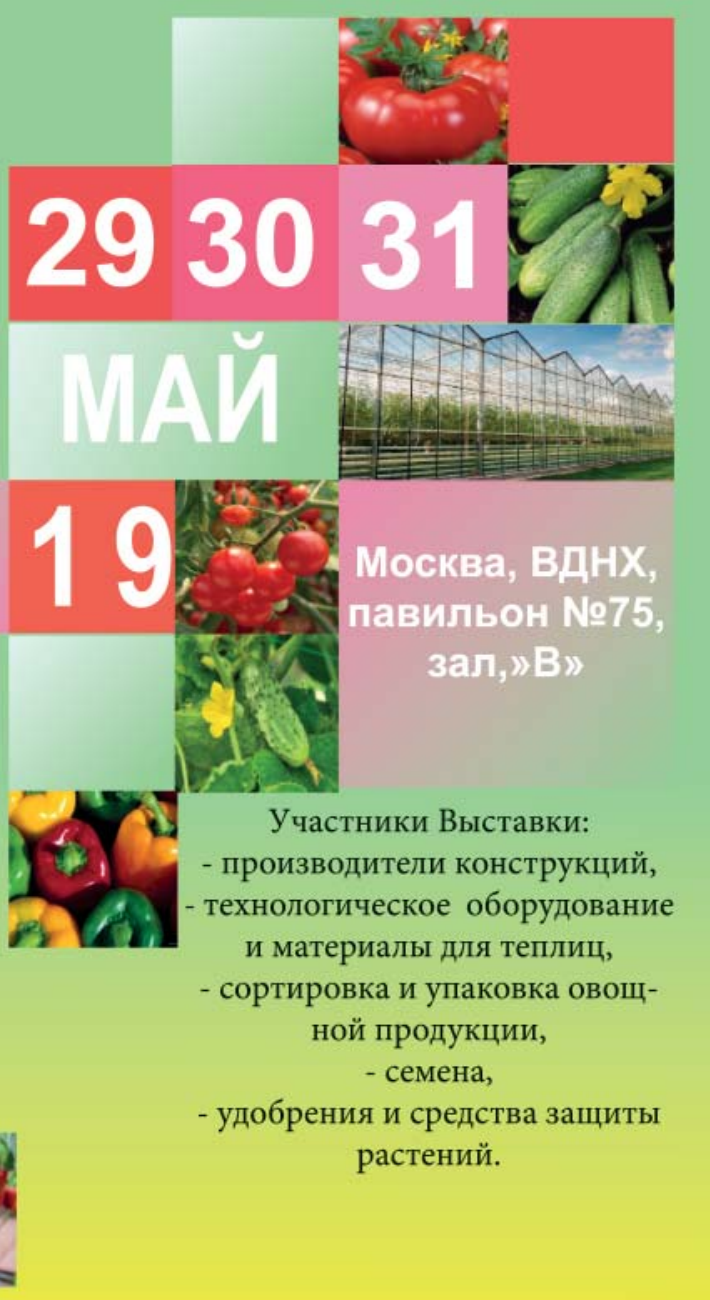

тел.: + 7.499.178.01.59

+7.495.651.08.39

e-mail: info@rusteplica.ru

http://rusteplica.ru

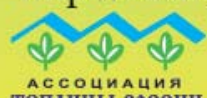

АсСОчИАчия
ТЕПКИЦЫ РОЯОИН



